\title{
Trace Metal Accumulation in Water, Soil and Crop Plants along the Basin of Ujjani Reservoir, India
}

\author{
Dnyaneshwar Shinde ${ }^{1,2}$, D. M. Mahajan ${ }^{1}$, Ashwini Pawar $^{2}$, Madhuri Kale², Sanjay Chakane,"* \\ ${ }^{1}$ Postgraduate Research Centre in Environmental Science, Baburaoji Gholap College, Sangvi, Pune, Maharashtra, India \\ ${ }^{2}$ Arts, Science and Commerce College, Indapur, Dist. Pune, Maharashtra, India
}

Received April 7, 2020; Revised June 5, 2020; Accepted June 16, 2020

\section{Cite This Paper in the following Citation Styles}

(a): [1] Dnyaneshwar Shinde, D. M. Mahajan, Ashwini Pawar, Madhuri Kale, Sanjay Chakane, "Trace Metal Accumulation in Water, Soil and Crop Plants along the Basin of Ujjani Reservoir, India," Advances in Zoology and Botany, Vol. 8, No. 5, pp. 453 - 460, 2020. DOI: 10.13189/azb.2020.080510.

(b): Dnyaneshwar Shinde, D. M. Mahajan, Ashwini Pawar, Madhuri Kale, Sanjay Chakane (2020). Trace Metal Accumulation in Water, Soil and Crop Plants along the Basin of Ujjani Reservoir, India. Advances in Zoology and Botany, 8(5), 453 - 460. DOI: 10.13189/azb.2020.080510.

Copyright $\bigcirc 2020$ by authors, all rights reserved. Authors agree that this article remains permanently open access under the terms of the Creative Commons Attribution License 4.0 International License

\begin{abstract}
The excessive application of fertilizers and of polluted irrigation water increases the trace metal level in an agricultural ecosystem. This study aimed to assess the concentrations of trace metals $(\mathrm{Fe}, \mathrm{Cu}, \mathrm{Mn}$, and $\mathrm{Zn})$ in irrigation water, field soil and crop plants. The contents of metals were analyzed by Atomic Absorption Spectroscopy. The range and hierarchy of trace metals concentration $(\mu \mathrm{g} / \mathrm{ml})$ in irrigation water are as follows, $\mathrm{Fe}(2.16-1.53)>$ $\mathrm{Zn}(0.30-0.17)>\mathrm{Cu}(0.18-0.11)>\mathrm{Mn}(0.11-0.09)$. The concentration $(\mu \mathrm{g} / \mathrm{g})$ range in field soil showed in an order as $\mathrm{Fe}(9000-6961.5)>\mathrm{Mn}(984.6-408.9)>\mathrm{Cu}$ $(698.5-26.3)>\operatorname{Zn}(145.3-22.9)$. Moreover, crop plant parts showed maximum concentration ( $\mu \mathrm{g} / \mathrm{g}$.dry weight) range for metal Fe (516.3 - 126.7) followed by Mn (169.7-0.4), $\mathrm{Zn}$ (78.8- 50) and least for metal $\mathrm{Cu}$ (70.5- 4.1). It was noticed that the Fe concentration in irrigation water is higher than the water quality standards proposed by the Food and Agriculture Organization. Furthermore, the field soil exhibited more $\mathrm{Cu}$, and crops have accumulated excess $\mathrm{Fe}$ and $\mathrm{Cu}$ than the Indian and European Union guidelines. Further, we reported that among the all plant part, leaves are more prone to accumulate trace metals. The value of the transfer factor indicates that plant has low bioaccumulation potential for studied trace metals. Whereas the accumulation index shows that there is a significant $\mathrm{Cu}$ contamination in the field soil. So we suggest that farmers should avoid the application of copper-rich fertilizers.
\end{abstract}

Keywords Trace Metals, Irrigation Water, Bioaccumulation, Ujjani Reservoir, Atomic Absorption
Spectroscopy

\section{Introduction}

The environmental pollution with trace metals has become a worldwide problem during recent years. Among the environmental pollutants, trace metals are of particular concern, because of their bioaccumulation potential in ecosystems [1,2]. Trace metal pollution in aquatic ecosystems is usually studied by measuring their concentrations in water, sediments and biota. It was noticed that their concentrations generally exist low levels in water and attain substantial concentration in sediments as well as biota. Trace metals such as $\mathrm{Fe}, \mathrm{Cu}, \mathrm{Ni}$, and $\mathrm{Cr}$ are essential metals since they play a central role in biological systems, whereas $\mathrm{Pb}$ and $\mathrm{Cd}$ considered as non-essential metals, they are toxic, yet in trace amounts. These essential metals can also create toxic effects when the metal ingestion is excessively high [3-5].

Agricultural soil and crops contaminated by trace metals becoming serious environmental problem. Their non-biodegradable nature and long biological half-life leads to their potential accumulation in different plants and animals' body parts. Trace metals such as $\mathrm{Zn}, \mathrm{Pb}, \mathrm{Cd}$ and $\mathrm{Cu}$ are generally found as contaminants in vegetables grown using polluted water. These trace metals enter into plants, animals, and humans through air and water. Trace 
metals exhibit bioaccumulation at the higher tropic level of the food chain [6-8]. Agricultural soils are mainly contaminated through irrigation water cause threats to resident's lives, due to consumption of crops and vegetables grown in contaminated areas [9]. There is a potential risk to human health due to the accumulation of trace metals in plants $[10,11]$. Trace metals such as $\mathrm{Pb}$ and $\mathrm{Cd}$ have shown carcinogenic effects on animals [12]. Elements such as $\mathrm{Zn}$ and $\mathrm{Cu}$ at higher concentrations cause toxic effects on living organisms. The higher dose of $\mathrm{Zn}$ can reduce immune function and levels of high-density lipoproteins [13,14]. Copper cause acute stomach and intestine aches and also liver damage [15].

Soil is a supporting layer for all organisms and acts as a medium for plant growth. Soil can absorb trace metals in the polluted river as well as groundwater and cause side effects on plant growth and metabolism [16]. Trace metals present in soil water and soil particles are absorbed by plant roots and accumulated in vegetables [17]. The natural concentration of trace metals in soil depends mainly on the composition of geological parent material, but it can also originate from anthropogenic activities [18]. Applications of compounds to soils and crops have become a common practice in crop cultivation. The purposes of the use of chemicals are the improvement of the nutrient supply in the soil or crop protection. These practices might cause chemical deprivation of soil, which result of accumulation of compounds at undesirable levels. Due to economic reasons, most fertilizers are generally not sufficiently purified at the time of the manufacturing process [19]. Extensive use of agrochemicals and inorganic fertilizers for higher crop yield are responsible for agricultural pollution and leads to degradation of the ecosystem and the environment [20]. Similarly, land application of sewage sludge, organic waste manure industrial by-products, and irrigation through highly polluted water are the main sources of trace metals into agricultural ecosystems [21]. Trace metal contamination of agricultural lands poses a latent threat to safe crop production globally, and to a great extent of effort has been spent to identify its sources of pollution [22].

In this study, we have assessed the bioaccumulation of trace metals $(\mathrm{Fe}, \mathrm{Cu}, \mathrm{Mn}$ and $\mathrm{Zn})$ in irrigation water, field soil and crop plant cultivated along the basin of Ujjani reservoir, spread in the Pune district of Maharashtra, India. Also, metal Transfer coefficient and Geoaccumulation index were calculated.

\section{Materials and Methods}

\subsection{Study Area}

The Ujjani reservoir (Topo sheet No. 47 N/4; Latitude $18004^{\prime} 24^{\prime \prime} \mathrm{N}$ and Longitude $75007^{\prime} 15^{\prime \prime} \mathrm{E}$ ) is located in the district Solapur of Maharashtra. Its catchment area is about $14856 \mathrm{Sq} . \mathrm{Km}$ [23]. This reservoir receives water from several rivers such as Mula, Mutha and Bhima which passes through metropolitan and industrialized cities namely Pune, Pimpri Chinchwad and Chakan. Finally, the river water is cached in Ujjani reservoir. The Ujjani reservoir water and sediment quality are declining day by day [24]. The study was carried during the spring season of 2019, in the village Malvadi, located $2 \mathrm{Km}$ apart from the basin of Ujjani reservoir. The Basin of the reservoir has intensive agricultural practices and variety of crop patterning such as sugarcane, banana, pomegranates, wheat, maize, and leafy vegetables. The water source used for irrigation is mainly from Ujjani reservoir and to some extent from Bore wells and Wells. Extensive applications of fertilizers, pesticides and long-term continuous irrigation to field soil cause degradation of soil fertility.

\subsection{Collection of Water, Soil, Plant Materials}

The water samples used for irrigation of field crops (banana, sugarcane and pomegranate) were collected from different sources such as Bore wells, Wells and Ujjani reservoir, separately in pre-cleaned bottles. Similarly, banana field soil (field A1, A2, A3), sugarcane field soil (field B1, B2, B3) and pomegranate field soil (field C1, C2, C3) were collected from 0 to $15 \mathrm{~cm}$ depth with the help of a plastic knife and transferred into polythene bags. The fresh plant parts such as fruits, leaves, and stem of banana, young leaves, mature leaves and stem of sugarcane and fruits and leaves of pomegranate were harvested separately at the mature stage of the crops. The irrigation water, field soil and harvested plant parts collected in triplicates and brought to the laboratory and processed further for acid digestion to analyze the content of trace metals.

\subsection{Preparation of Water, Soil and Plant Samples}

In order to determine the trace metal contents in irrigation water, initially water samples were treated with 3 $\mathrm{ml}$ of $70 \%$ concentrated $\mathrm{HNO}_{3}$. Later, to concentrate sample, $500 \mathrm{ml}$ of the water sample was evaporated separately for 3 hours on a hot plate. Next, samples were digested using $3-5 \mathrm{ml}$ of $70 \%$ concentrated $\mathrm{HNO}_{3}$ at $140^{\circ} \mathrm{C}$ on a hot plate until the volume reduced to $25-30 \mathrm{ml}$. Similarly, the field soil samples collected were initially oven-dried at $105^{\circ} \mathrm{C}$, for $10-20$ hours then ground and sieved through plastic mesh having a pore size $0.5 \mathrm{~mm}$ afterward weighed $0.5 \mathrm{~g}$ and digested with a mixture of concentrated $\mathrm{HNO}_{3}$ and $\mathrm{HClO}_{4}(3: 1)$, initially at $40^{\circ} \mathrm{C}$ for 1 hour, followed by $140-160^{\circ} \mathrm{C}$ for 2 hours on a hot plate. Plant parts harvested were washed with tap water, followed by deionized water, oven-dried at $85^{\circ} \mathrm{C}$, for $10-12$ hours. Furthermore, powdered samples were meshed through 0.5 $\mathrm{mm}$ plastic mesh, weighted $0.5 \mathrm{~g}$ each and digested separately using a mixture of concentrated $\mathrm{HNO} 3$ and $\mathrm{HCl}$ (3:1), initially at $40^{\circ} \mathrm{C}$ for 1 hour, followed by $120^{\circ} \mathrm{C}$ to 140 
${ }^{\circ} \mathrm{C}$ for 2 hours on a hot plate. All, digested samples such as water, field soil and plant parts were filtered through a Watman filter paper (45Micron), subsequently diluted with double-distilled water to make a final volume to $50 \mathrm{ml}$. The concentrations of the trace metals were determined by AAS (Sistronic Model- 263).

\subsection{Statistical Analysis}

The concentrations of trace metals obtained in various samples after analysis by AAS were subjected to analysis of mean, standard deviation and standard errors.

\subsection{Transfer Coefficient}

The transfer coefficient of trace metals from soil to plant body was calculated by dividing the mean concentration of trace metals in $t$ respective plant by the mean trace metals concentration in the respective soil field [25].

$$
\mathrm{TF}=\mathrm{C} \text { plant } / \mathrm{C} \text { soil }
$$

Where, $\mathrm{C}$ plant $=$ mean trace metal concentration in plant body $(\mu \mathrm{g} / \mathrm{g})$ and $\mathrm{C}$ soil $=$ mean trace metal concentration in soil $(\mu \mathrm{g} / \mathrm{g})$. The metal concentrations in the extracts of the field soils and plants were calculated on the basis of dry weight. If the ratios $>1$, the plants have accumulated trace metals, the ratios around 1 indicate that the plants are not influenced by the trace metals, and ratios $<1$ indicate that plants eliminate the elements from the uptake [26].

\subsection{Geoaccumulation Index (Igeo)}

The degree of contamination from the trace metals can be assessed using the geoaccumulation index $\left(\mathrm{I}_{\text {geo }}\right)$. The geoaccumulation index has been commonly applied to the assessment of sediment and soil contamination [27]. The level of pollution in sediment and soil were characterized by calculating geoaccumulation index $\left(\mathrm{I}_{\text {geo }}\right)$ values using the following equation,

$$
\mathrm{I}_{\text {geo }}=\log _{2} \frac{C n}{1.5 \times B n}
$$

Where, $\mathrm{Cn}$ is the concentration $(\mu \mathrm{g} / \mathrm{g})$ of metal in the soil and $\mathrm{Bn}$ is the geochemical background value of element) in the background sample [28]. Geochemical background values (in $\mu \mathrm{g} / \mathrm{g}$ ) for metal $\mathrm{Fe}, \mathrm{Cu}, \mathrm{Mn}$ and $\mathrm{Zn}$ are $35000,25,600,71$ respectively. The factor 1.5 is introduced to decrease the possible variations in the background values which may be ascribed to lithogenic effects. Geoaccumulation $\left(\mathrm{I}_{\text {geo }}\right)$ index values interpreted as, $\mathrm{I}_{\text {geo }} \leq 0$, uncontaminated, $0 \leq \mathrm{I}_{\text {geo }} \leq 1$ uncontaminated to moderately contaminated, $1 \leq \mathrm{I}_{\text {geo }} \leq 2$ moderately contaminated, $2 \leq \mathrm{I}_{\text {geo }} \leq 3$ moderately to heavily contaminated, and $3 \leq \mathrm{I}_{\text {geo }} \leq 4$ heavily contaminated and $4 \leq$ $\mathrm{I}_{\text {geo }} \leq 5$ heavily to extremely contaminated and $\mathrm{I}_{\text {geo }} \geq 5$ extremely contaminated.

\section{Results}

\subsection{Trace Metals in Irrigation Water}

In this study, the content of trace metals such as $\mathrm{Fe}, \mathrm{Cu}$, $\mathrm{Mn}$ and $\mathrm{Zn}$ were assessed in various irrigation water sources such as Bore wells, Wells and Ujjani reservoir. (Figure1). The results indicate that the concentration of metal Fe was observed uppermost than other studied metals. The maximum concentration of Fe observed in Wells water followed by bore wells and Ujjani reservoir water. The concentration of $\mathrm{Fe}$ in Bore wells and Ujjani reservoir water did not show a significant difference. Also, the concentration of $\mathrm{Cu}$ detected more in Wells water and least in Bore well water. Whereas Mn content showed a reverse trend, Mn content was observed highest in Bore well and lowest in Well water. It was detected that the Ujjani reservoir has the highest $\mathrm{Zn}$ concentration than the other two water sources studied. The concentration of trace metals in all water sources used for irrigation showed descending order such as $\mathrm{Fe}>\mathrm{Zn}>\mathrm{Cu}>\mathrm{Mn}$ (Figure 1). We observed that except Fe, other studied metals in water samples are below the standers proposed by the Food and Agriculture Organization [37] (Table1).

\subsection{Trace Metals in Soil}

The trace metal ( $\mathrm{Fe}, \mathrm{Cu}, \mathrm{Mn}$ and $\mathrm{Zn}$ ) concentrations were analyzed from different field soil. The field soil samples were collected from banana (field A1, A2, A3), sugarcane (B1, B2, B3) and pomegranate (field C1, C2, C3) field respectively. (Figure1.) The content of $\mathrm{Fe}$ in banana, sugarcane and pomegranate field soil were observed in the descending order such as $\mathrm{A} 1>\mathrm{A} 3>\mathrm{A} 2, \mathrm{~B} 3>\mathrm{B} 2>\mathrm{B} 1$ and $\mathrm{C} 1>\mathrm{C} 2>\mathrm{C} 3$ respectively. It was found that the concentration of $\mathrm{Fe}$ in banana field soil was more than the sugarcane and pomegranate field soil. Similarly, the $\mathrm{Cu}$ content in banana, sugarcane and pomegranate field soil was observed in the descending order such as A1 $>$ A2 $>$ A3, $\mathrm{B} 3>\mathrm{B} 2>\mathrm{B} 1, \mathrm{C} 2>\mathrm{C} 1>\mathrm{C} 3$ respectively. The field soil under cultivation of banana showed a drastic decrease in the $\mathrm{Cu}$ content than pomegranate and sugarcane field soil. Moreover, the Mn concentration in banana, sugarcane and pomegranate field soil showed the hierarchical order such as $\mathrm{A} 3>\mathrm{A} 2>\mathrm{A} 1, \mathrm{~B} 2>\mathrm{B} 3>\mathrm{B} 1$ and $\mathrm{C} 2>\mathrm{C} 1>\mathrm{C} 3$ respectively. It was detected that there, is no significant variation in Mn content among the banana and sugarcane field soil. The mean content of $\mathrm{Zn}$ was observed highest in the banana field soil followed by pomegranate and least in sugarcane field soil. In the banana, sugarcane and pomegranate field, $\mathrm{Zn}$ accumulation exhibited order such as $\mathrm{A} 3,>\mathrm{A} 2>\mathrm{A} 1, \mathrm{~B} 3>\mathrm{B} 2>\mathrm{B} 1$ and $\mathrm{C} 3>\mathrm{C} 2>\mathrm{C} 1$ respectively (Figure 1). Among the trace metals under study, Fe content was more in all studied field soil followed by $\mathrm{Mn}, \mathrm{Cu}$, and $\mathrm{Zn}$. Accumulation of metal $\mathrm{Cu}$ in field soil was observed more than the permissible limit proposed by the European Union [30] and Indian standards [29]. 
Table 1. Indian, European Union and FAO standards for trace metal contents in water, field soil and plant parts

\begin{tabular}{|c|c|c|c|c|}
\hline Sample type & $\mathrm{Fe}$ & $\mathrm{Cu}$ & $\mathrm{Mn}$ & $\mathrm{Zn}$ \\
\hline Water -Indian standards [29] & 0.05 & 0.1 & 5 & 0.3 \\
\hline FAO (1985) & 0.2 & 0.2 & 2 & 0.5 \\
\hline Soil- Indian standard [29] & 50,000 & $135-270$ & $100-4000$ & $300-600$ \\
\hline E. U. Standards [30] & & 100 & 2000 & 300 \\
\hline Plant Parts -Indian standard [29] & 20 & 30 & & 50 \\
\hline E. U. standards [31] & & 20 & 500 & 50 \\
\hline
\end{tabular}

Description: Standard values for trace metal contents in irrigation water $(\mu \mathrm{g} / \mathrm{ml})$, field soil $(\mu \mathrm{g} / \mathrm{g})$, and plant parts $(\mu \mathrm{g} / \mathrm{g}$ dry weight). EU European Union, FAO Food and Agriculture Organization.
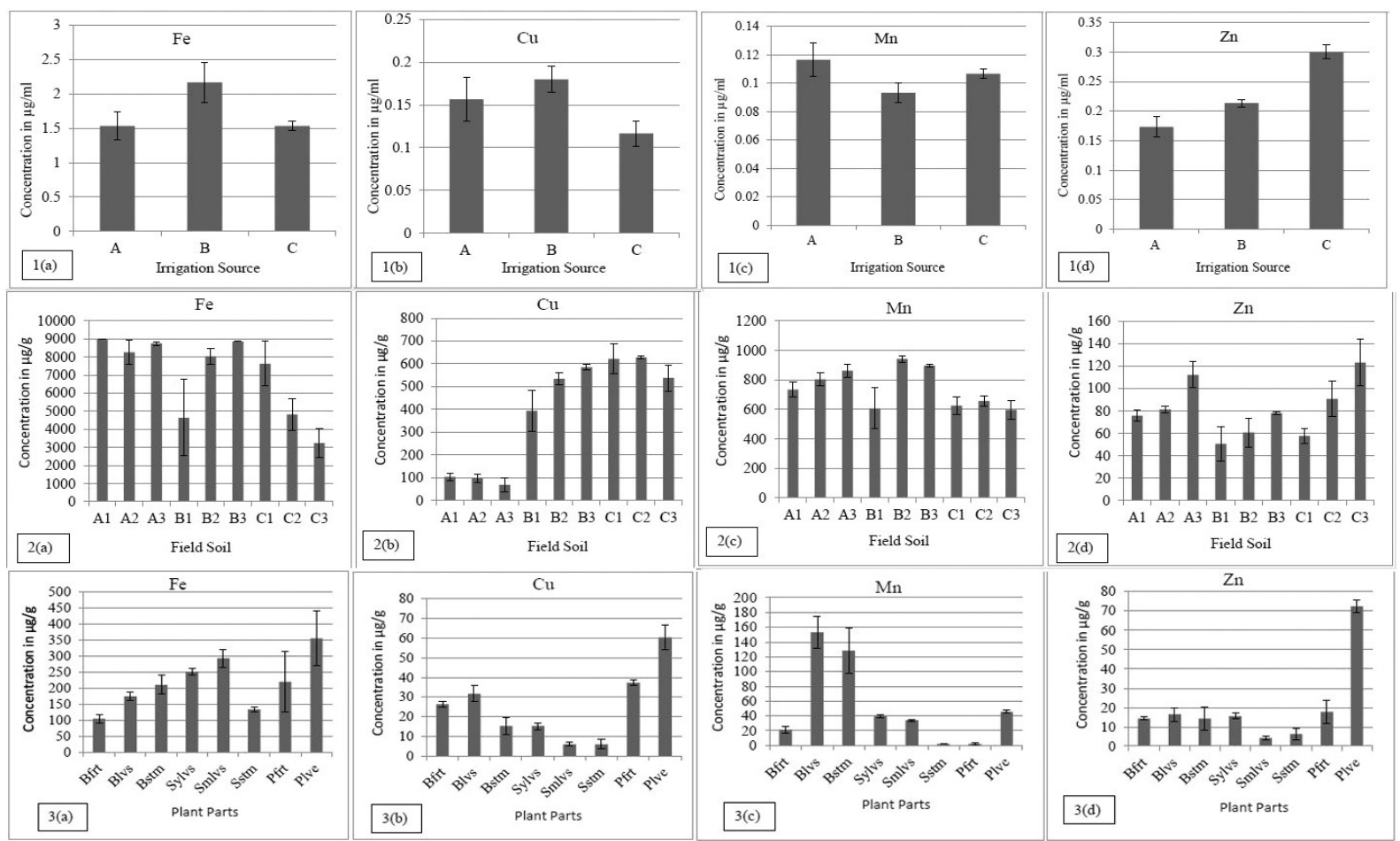

Description: Concentrations of Fe (1a), (2a), (3a); Cu (1b), (2b), (3b); Mn (1c), (2c), (3c) and Zn (1d), (2d), (3d) in irrigation water( $\mu \mathrm{g} / \mathrm{ml})$, field soil $(\mu \mathrm{g} / \mathrm{g})$ and plant parts $(\mu \mathrm{g} / \mathrm{g}$ dry weight $)$ respectively. A, B and C indicates irrigation water source such as Bore wells, Wells, and Ujani reservoir respectively. A1, A2, A3; B1, B2, B3; C1, C2, and C3 are the banana, sugarcane and pomegranate field soil respectively. Bfrt, Blvs, Bstm are the banana fruits, leaves and stem. Sylvs, Smlvs, Sstm are the sugarcane young leaves, mature leaves and stem. Pfrt, Plve are pomegranate fruits and leaves. Mean and standard errors are compared ( $\mathrm{n}=3$ for all samples).

Figure 1. Trace metal concentrations in water, field soil and plant parts

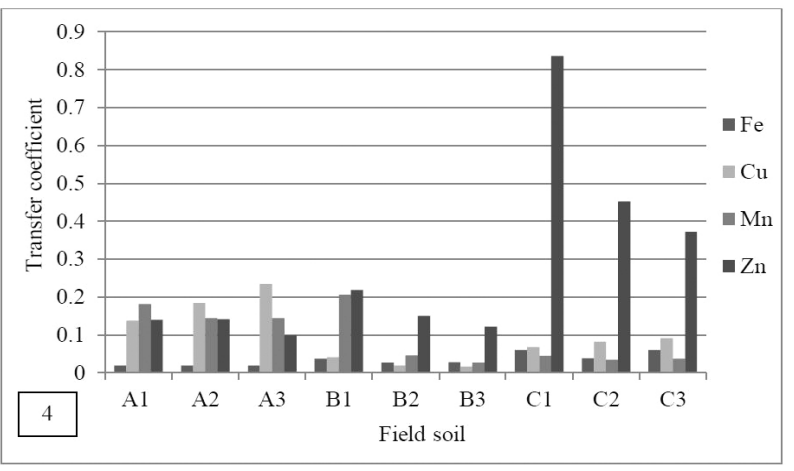

Description: Trace metal transfer factor from soil to plants. Where, A1, $\mathrm{A} 2$, and $\mathrm{A} 3$ are banana field soil, B1, B2, and B3 are sugarcane field and $\mathrm{C} 1, \mathrm{C} 2$, and $\mathrm{C} 3$ are pomegranate field.

Figure 2. Trace metal transfer factor from soil to plants

\subsection{Trace Metals in Crops}

The highest $\mathrm{Fe}$ concentration was detected in stem followed by leaves and least in fruits of banana, whereas in case of sugarcane plant parts mature leaves showed maximum Fe followed by young leaves and lesser in the stem. Moreover in pomegranate, the maximum concentration of Fe was detected in leaves followed by fruits. Among the plant parts under study metal $\mathrm{Fe}$ was detected more than $\mathrm{Cu}, \mathrm{Mn}$ and $\mathrm{Zn}$. The metal $\mathrm{Cu}$ contents in banana was more in leaves afterward in fruits and less in the stem, whereas sugarcane young leaves accumulate more $\mathrm{Cu}$ than mature leaves and stem. Among the plant parts understudy, $\mathrm{Cu}$ concentration in pomegranate leaves and fruits were significantly high. Also, significant 
variation in the Mn level was noticed within the leaves and fruits of banana. The order of Mn contents in banana showed leaves $>$ stem followed by fruits. In the case of sugarcane Mn showed concentration order such as young leaves $>$ mature leaves and least in the stem. Also, pomegranate leaves accumulate higher $\mathrm{Mn}$ than fruits. Accumulation of metal $\mathrm{Zn}$ in banana plant parts did not show significant variation. However, sugarcane parts under study detected higher $\mathrm{Zn}$ contents in young leaves than mature leaves and stem. Similarly, Zn contents in pomegranate leaves were detected highest among all plant parts under study. It was generally noticed that among all plant parts understudy leaves accumulate more trace metals.

\subsection{Transfer Factor}

The transfer factor (TF) for banana field soil A1 (Mn > $\mathrm{Zn}>\mathrm{Cu}>\mathrm{Fe}), \mathrm{A} 2$ and $\mathrm{A} 3(\mathrm{Cu}>\mathrm{Mn}>\mathrm{Zn}>\mathrm{Fe})$ showed the lowest value for metal $\mathrm{Fe}$. However, in the sugarcane field soil $\mathrm{B} 1, \mathrm{~B} 2$ and $\mathrm{B} 3(\mathrm{Zn}>\mathrm{Mn}>\mathrm{Fe}>\mathrm{Cu}$.) exhibited minimum $\mathrm{TF}$ for metal $\mathrm{Cu}$ and highest for $\mathrm{Zn}$, whereas in pomegranate field soil $\mathrm{C} 1, \mathrm{C} 2, \mathrm{C} 3(\mathrm{Zn}>>\mathrm{Cu}>\mathrm{Fe}>\mathrm{Mn})$ lowest TF was observed for metal Mn (Figure 2).

It was noticed that the transfer of $\mathrm{Zn}$ was higher in sugarcane and pomegranate, However metal $\mathrm{Mn}$ and $\mathrm{Cu}$ transfer more easily in banana plant. All values of studied TF were below the 1 , indicating that studied plants are not contaminated by trace metals [28].

\subsection{Geoaccumulation Index}

The values geoaccumulation index detected for metal $\mathrm{Fe}$, $\mathrm{Mn}$ and $\mathrm{Zn}$ were below the 1 indicating field soil is not contaminated by Fe, Mn and $\mathrm{Zn}$, whereas field soil A1 and A2, $\left(2>\mathrm{I}_{g e o}>1\right)$ is moderately contaminated. Field soil B1 and B2 $\left(3<\mathrm{I}_{g e o}>4\right)$ is heavily contaminated, and field soil $\mathrm{C} 1$ and $\mathrm{C} 4\left(\mathrm{I}_{\text {geo }}>4\right)$ is heavy to extremely contaminated.

\section{Discussion}

In this study we have investigated metal contamination and its distribution pattern in irrigation water, field soil and crop plants along the basin of Ujjani reservoir. Generally, micronutrients are beneficial to plant growth in adequate quantity, but its abundance causes deleterious effects. In general, among the metals, Fe content is observed more than other metals in irrigation water, and plant parts. Iron $(\mathrm{Fe})$ is an essential micronutrient in a plant but excess iron is highly toxic to plants. The excess Fe retards primary and lateral growth of roots $[32,33]$. It is reported that $\mathrm{Fe}$ toxicity in rice cropping system minimizes grain size and also yield. Also, chronic exposure of Fe through food in humans causes constipation, nausea, diarrhea and chronic ulcerations. Here, in our work, the concentration of Fe in irrigation water and plant parts observed more than the limit prescribed by the Food and Agriculture Organization [34] European Union [30] and Indian standards [29].

To acquire further insight into the other metal content we determined $\mathrm{Cu}$ level and it was drastically higher in field soil and plant parts under study. Copper is essential for plant nutrients, but concentration more than $270 \mu \mathrm{g} / \mathrm{g}$ considered as toxic to soil health. The toxic effects of $\mathrm{Cu}$ are studied in several crop species. Soil's $\mathrm{Cu}$ level more than $300 \mu \mathrm{g} / \mathrm{g}$ cause decrease in 50 percent yield of rice grains [35]. Accumulation of $\mathrm{Cu}$ could be occurring due to applications excess essential elements for plant growth as remedies for deficiency in the soil. Application of biosoilid sands, fertilizers and manure to field soil causes accumulation of metals such as $\mathrm{Cu}, \mathrm{Zn}, \mathrm{Fe}, \mathrm{Pb}$ and $\mathrm{Mn}$ in the soil [13].

The degree of contamination in soil is studied by total trace metal concentration [7]. The accumulation of trace metals in field soil depends on a range of factors, such as soil $\mathrm{pH}$, the chemical form of element, texture, cation exchange capacity of the soil and its organic matter contents [36].

The higher level of soil trace metals may pose health problems in residential [37]. The Mn phytotoxicity is manifested in a reduction of biomass and photosynthesis, and biochemical disorders such as oxidative stress [38]. The Mn concentration observed in this study was found lower than previously detected in polluted soil [39]. It representing that the $\mathrm{Mn}$ has no significant contamination in the studied field soil samples. Also, irrigation water and plant parts show a lower accumulation of Mn than the permissible limit prescribed by the standards proposed by the European Union [30] and India [29].

The contents of $\mathrm{Zn}$ observed in all samples collected were bellowing the permissible limit. Although $\mathrm{Zn}$ is an essential element for plant metabolism, excess level of $\mathrm{Zn}$ causes browning of leaves and reduction in chlorophyll contents and photosynthesis. We noticed that Ujjani reservoir water contains more $\mathrm{Zn}$ levels than other sources. Soil $\mathrm{Zn}$ level more than $500 \mu \mathrm{g} / \mathrm{g}$ cause a drastic reduction in photosynthetic activity of plant [40].

The uptake and release of metals in the plant depend on soil composition, plant species, and plant growth stage. The trace metals concentrations in plant organs are generally lower than field soil. Demirezen and Aksoy[37] reported the trace metal concentrations are lower in vegetables than soil. It was reported that $\mathrm{Cu}$ contents in urban soil (63.39-110.3 $\mu \mathrm{g} / \mathrm{g})$ ranges higher than the vegetables $(22.19-76.5 \mu \mathrm{g} / \mathrm{g})$ grown on those soil. Similarly, metal $\mathrm{Zn}$ in urban soil ranges from 44.3-294.4 $\mu \mathrm{g} / \mathrm{g}$, and in vegetables between 3.56-259.2 $\mu \mathrm{g} / \mathrm{g}$ [37]. The vegetable grown on trace metal contaminated soil accumulates elevated concentration of metals in their edible parts. The high level of trace metals in the soil does not always indicate high concentrations in plant parts. Accumulation of trace metals in the plant depends on 
environmental factors and plant species [41]. The level of all studied elements was observed higher in leaves than in other parts. Accumulation of particular metals in plant leaves, stem and fruits depend on the type and species of plant. It was noticed that pomegranate leaves accumulate more $\mathrm{Fe}(355.4 \mu \mathrm{g} / \mathrm{g}), \mathrm{Cu}(60.3 \mu \mathrm{g} / \mathrm{g})$, and $\mathrm{Zn}(72.3 \mu \mathrm{g} / \mathrm{g})$, than the leaves of other plants. Similarly leaves of banana showed more Mn $(153.3 \mu \mathrm{g} / \mathrm{g})$ than the other plant parts studied. The concentration of metal Fe $(8976.4 \mu \mathrm{g} / \mathrm{g})$ in the banana field soil was observed higher, whereas, $\mathrm{Cu}$ (628.4) and $\mathrm{Zn}(122.9 \mu \mathrm{g} / \mathrm{g})$ were observed more in pomegranate field. Further, Mn $(943 \mu \mathrm{g} / \mathrm{g})$ was detected more in sugarcane cultivated filed soil. Moreover, the level of metal contents obtained in this study were compared with international standards and noticed that $\mathrm{Cu}$ contents in field soil was found more, whereas other metals were within the safe limit. Also the level of metal $\mathrm{Fe}$, and $\mathrm{Cu}$ in some plants parts detected more than the international standards (Table 1). Variations in the level of trace metal composition in the field soil may be due to applications of crop specific fertilizers, pesticides and frequency of water irrigation. The results of our study showed that accumulation of trace metals mainly depends on type of crop species. Even higher contents of metals in the field soil, accumulation in the plants parts did not showed peak concentration value.

In order to study contamination of trace metals in plant and field soil is estimated using transfer factor (TF) and Geoaccumulation Index $\left(\mathrm{I}_{\mathrm{geo}}\right)$. These factors are influenced by an excess of metal levels in soil and plant. The concentration range of trace metals in the field soil varies with the type of metal and crop plant patterning. It may be occurred by the application of crop-specific fertilizers [42]. The concentrations of studied metals in field soil showed the order such as $\mathrm{Fe}>\mathrm{Mn}>\mathrm{Cu}>\mathrm{Zn}$. The concentration of metals in the soil also depends on their concentration in the upper continental crust [43]. The transfer coefficient of studied metals from soil to plant is species-specific. The metal $\mathrm{Zn}$ transfers more efficiently in Pomegranate and Sugarcane, whereas metal $\mathrm{Cu}$ and $\mathrm{Mn}$ transfer more efficiently in banana. However, the transfer coefficient is less than 1 in all studied plants. It may be due to the unique metabolic activity of particular plant species. We observed that $\mathrm{I}_{\text {geo }}$ values for $\mathrm{Fe}, \mathrm{Mn}$ and $\mathrm{Cu}$ were lesser than unity indicating field soil is not contaminated. Whereas $\mathrm{I}_{\text {geo }}$ of metal $\mathrm{Cu}$ reached up to 5 indicating that field soil is extremely contaminated with copper.

\section{Conclusions}

Present study was conducted to evaluate the impact of modern agriculture activities on the environmental quality and food safety. Excessive use of fertilizers and pesticides to increase crop yield are responsible for increasing concentrations of some toxic metals into the soil and crops cultivated on those soil. Moreover, trace metals are essential for normal growth and development but excessive accumulation of these metals causes adverse effects on plant. This metal enters into the human and other animals through food chain and causes toxicity. Ujjani reservoir is main irrigation water source in the study area. Industrializations, urbanizations and agriculture development are responsible for addition of elements into the agriculture ecosystem. Different irrigation water sources assessed indicate that except metal Fe, the content of trace metals found are below the environmental standards. Water from Wells and Ujjani reservoir contains higher $\mathrm{Fe}$ and $\mathrm{Zn}$ respectively. Whereas $\mathrm{Cu}$ and $\mathrm{Mn}$ were found more in bore well water samples. Similarly, the concentrations of trace metals in studied field soil vary with crop plant cultivation pattern. It was noticed that $\mathrm{Cu}$, $\mathrm{Mn}$ and $\mathrm{Zn}$ were detected more in pomegranate field soil. It indicated that the application of crop-specific fertilizer and pesticides may affect the level of a contaminant in the field soil. The concentrations of trace metals in studied plant parts indicate that there is a higher accumulation in leaves. It may be due to the unique metabolic activity of leaves. Also, the accumulation of trace metals depends on plant species and types of organs and not always on their soil contents. Even more metal contents in the soil do not always give higher accumulations in plant parts. Transfer factors calculated is bellowing the unity, indicating that studied crop plant has lower phytoremediation potential. It is also noticed that $\mathrm{I}_{\mathrm{geo}}$ value of metal $\mathrm{Cu}$ is more than 4; indicating soil is highly contaminated by Copper. Further we suggest that farmers should analyze soil and water trace metal profile before application of fertilizers to crops. Also, government environment agency needs to monitor soil and water qualities periodically for safe food production and environmental sustainability.

\section{Acknowledgements}

The authors wish to acknowledge ITSPM'S, Arts Science and Commerce College, Indapur for making available instrumentation facilities. Also, we wish to acknowledge Dr. Pramod Kambale (Department of Environmental Science, Savitribai Phule Pune University) and Dr. J.P. Sarwade (Department of Zoology, A.S.C. College Indapur) for providing laboratory facilities.

\section{Declaration of Interest Statement}

The authors declared that they have no conflicts of interest in this work. We do not have any commercial or associative interest that represents a conflict of interest in connection with the work submitted. 


\section{REFERENCES}

[1] Censi P, Spoto SE, Saiano F, Sprovieri M, Mazzola S, Nardone G, Di Geronimo SI et al. Heavy metals in coastal water systems. A case study from the northwestern Gulf of Thailand, Chemosphere, Vol. 64, No.7, 1167-1176, 2006.

[2] Journal E, Studies, E, Vol M. Trace Metals Distribution in Fish Tissues, Bottom Sediments and Water from Okumeshi River in Delta State, Nigeria 1 Ekeanyanwu * C.R. 1 Ogbuinyi C.A 1 and 2 Etienajirhevwe O.F., Ethiopian Journal of Environmental Studies and ManagementVol.3, No.3, 12-17, 2010.

[3] Fernandes C, Fontaínhas-Fernandes A, Cabral D, Salgado MA. Heavy metals in water, sediment and tissues of Liza saliens from Esmoriz-Paramos lagoon, Portugal. Environmental Monitoring and Assessment,Vol.136, No.1-3, 267-275, 2008.

[4] Tüzen M. Investigation of heavy metal levels in street dust samples in Tokat, Turkey. Journal of Trace and Microprobe Techniques, Vol. 21, No.3, 513-521, 2003.

[5] Shinde D, Kamble P, Mahajan DM, Devkar V, Chakane S. Analysis of Accumulated Heavy Metal Concentrations in Various Body Parts of Chillapi ( Oreochromis mossambicus ) Fish from Ujjani Reservoir. Advances in Zoology and Botany, Vol. 8, No.2, 37-44, 2020.

[6] Radwan MA, Salama AK. Market basket survey for some heavy metals in Egyptian fruits and vegetables. Food and Chemical Toxicology, Vol.44, No.8, 1273-1278, 2006.

[7] Karaca A, 2004. Effect of organic wastes on the extractability of cadmium, copper, nickel, and zinc in soil. Geoderma,Vol. 122, No.2-4 SPEC. IIS, 297-303.

[8] Nagajyoti PC, Lee KD, Sreekanth TVM. Heavy metals, occurrence and toxicity for plants: A review. Environmental Chemistry LettersVol. 8, No. 4, 199-216, 2010.

[9] Kumar Sharma R, Agrawal M, Marshall F. Heavy metal contamination of soil and vegetables in suburban areas of Varanasi, India. Ecotoxicology and Environmental SafetyVol. 66, No. 2, 258-266, 2007.

[10] Chauhan G. Toxicity study of metals contamination on vegetables grown in the vicinity of cement factory.Vol. 4, No. 11), 1-9, 2014.

[11] Alghobar MA, Suresha S. Evaluation of metal accumulation in soil and tomatoes irrigated with sewage water from Mysore city, Karnataka, India. Journal of the Saudi Society of Agricultural SciencesVol. 18, No. 4, 49-59, 2017.

[12] Jaishankar M, Tseten $T$, Anbalagan N, Mathew BB, Beeregowda KN. Toxicity, mechanism and health effects of some heavy metals.Interdisciplinary Toxicology, Vol. 7,No.2 60-72, 2014.

[13] Weissmannová HD, Pavlovský J. Indices of soil contamination by heavy metals - methodology of calculation for pollution assessment (minireview). Environmental Monitoring and AssessmentVol. 189, No.12, 1-25, 2017.

[14] Harmanescu M, Alda LM, Bordean DM, Gogoasa I, Gergen I. Heavy metals health risk assessment for population via consumption of vegetables grown in old mining area; a case study: Banat County, Romania. Chemistry Central Journal, Vol. 5, No.1, 64, 2011.

[15] Gaetke LM, Chow CK.Copper toxicity, oxidative stress, and antioxidant nutrients. Toxicology Vol. 189, No.2003 147$163,2003$.

[16] Aweng E, Karimah M, Suhaimi O. Heavy metals concentration of irrigation water, soils and fruit vegetables in Kota Bharu Area, Kelantan, Malaysia. Journal of Appllied. Sciences, Vol. 6, No.4, 463-470, 2011.

[17] Hussain A, Riyas S, Isolation of heavy metal content in vegetables". Electronic Journal of Environmental, Agricultural and Food Chemistry,Vol. 11, No.2, 128-135, 2012.

[18] Shan Y, Tysklind M, Hao F, Ouyang W, Chen S, Lin C. Identification of sources of heavy metals in agricultural soils using multivariate analysis and GIS". Journal of Soils and Sediments,Vol.13, No.4, 720-729, 2013.

[19] Gimeno-García E, Andreu V, Boluda R, Heavy metals incidence in the application of inorganic fertilizers and pesticides to rice farming soils. Environmental Pollution, Vol. 92, No1, 19-25, 1996.

[20] Sarkar A, Singh RP. Agroecological Responses of Heavy Metal Pollution with Special Emphasis on Soil Health and Plant Performances. Frontiers in Environmental Science, Vol. 5, 1-19, 2017.

[21] Woldetsadik D, Drechsel P, Keraita B, Itanna F, Gebrekidan $\mathrm{H}$. Heavy metal accumulation and health risk assessment in wastewater-irrigated urban vegetable farming sites of Addis Ababa. Frontiers in Environmental Science, Vol.5: 1-19, 2017.

[22] Chen T, Liu X, Zhu M, Zhao K, Wu J, Xu J, Huang P. Identification of trace element sources and associated risk assessment in vegetable soils of the urban e rural transitional area of Hangzhou, China" Environmental pollution, Vol. 151, 67-78, 2008.

[23] Joshi, S, Kodarkar M, n.d. Ujjani Reservoir in Pune District, Maharashtra, India: A World Lake Vision Candidate Waiting for Ecological Restoration.

[24] Shinde DR, Mahajan DM, Sarwade JP, Vikas S. Accumulation of Some Heavy Metals in Sediment and Water of Ujjani Reservoir, Maharashtra, India. Advances in Environmental Ressearch(Foutrthcomming).

[25] Agic R, Skopje F, Milenkovic L. Ilic ZS. 2015a. Transfer Factor as Indicator, 2015a.

[26] Olowoyo JO, Heerden E. Van Fischer JL, Baker C, Trace metals in soil and leaves of Jacaranda mimosifolia in Tshwane area, South Africa. Atmospheric EnvironmentVol. 44, No. 14, 1826-1830, 2010.

[27] Santos Bermejo JC, Beltrán R, Gömez Ariza JL.Spatial variations of heavy metals contamination in sediments from Odiel river (Southwest Spain). Environment International, Vol. 29, No.1, 69-77, 2003.

[28] Taylor SR, Mclennan SM.The Geochemical The Continental Evolution Crust of Stuart. American Geophysical Union, Vol.33, No.2, 241-265, 1995.

[29] Awashthi, SK. Prevention of Food Adulteration Act No 37 
of 1954. Central and state rules as amended for 1999'. $3^{\text {rd }}$ edition. New Delhi, India: Ashoka Law House: New Delhi, 2002.

[30] Report F. Heavy Metals in Waste Heavy Metals in Waste 2002.

[31] EU. Setting Maximum Levels for Certain Contaminants in Food Stuffs. Commission regulation (EC) No. 1881/2006. Official Journal of European Union L364/5, 2006.

[32] Li G, Kronzucker HJ, Shi W, 2016. Root developmental adaptation to Fe toxicity: Mechanisms and management. Plant Signaling and Behavior,Vol.11, No.1, 1-3, 2016.

[33] Genon, JG, de Hepcee N, Duffy JE, Delvaux B, Hennebert PA, Iron toxicity and other chemical soil constraints to rice in highland swamps of Burundi. Plant and Soil, Vol.166(1): 109-115, 1994.

[34] RS Ayers, DW Westcot. Water Quality for Agriculture. Paper No. 29 (Rev. 1). Food and Agriculture Organization of the United Nations, Rome: UNESCO, Publication, Rome, 1985.

[35] Xu J, Yang L, Wang Z, Dong G, Huang J, Wang Y.Toxicity of copper on rice growth and accumulation of copper in rice grain in copper contaminated soil. Chemosphere,Vol.62 No.4, 602-607, 2006.

[36] Logan TJ, Chaney RL. Utilization of municipal wastewater and sludge on land-metals. in: A.L. Page et al. (ed.) Proceeding of the 1983 Workshop on utilization of municipal wastewater and sludge on land. University of California, 235-26, 1983.
[37] Demirezen D, Aksoy A.Heavy metal levels in vegetables in Turkey are within safe limits for $\mathrm{Cu}, \mathrm{Zn}, \mathrm{Ni}$ and exceeded for $\mathrm{Cd}$ and Pb. Journal of Food Quality, Vol. 29, No.3,252-265, 2006.

[38] Millaleo R, Reyes-Díaz M, Ivanov AG, Mora ML, Alberdi M. Manganese as essential and toxic element for plants: Transport, accumulation and resistance mechanisms. Journal of Soil Science and Plant NutritionVol.10, No.4, 476-494, 2010 .

[39] Obiora SC, Chukwu A, Chibuike G, Nwegbu AN Potentially harmful elements and their health implications in cultivable soils and food crops around lead-zinc mines in Ishiagu, Southeastern Nigeria. Journal of Geochemical Exploration, Vol. 204, (April):289-296, 2019.

[40] Venkatesan S, Hemalatha KV, Jayaganesh S. Zinc Toxicity and its Influence on Nutirent Uptake in Tea". American Journal of Plant Physiology,Vol.1, No.2, 185-192, 2006.

[41] Filipović-Trajković R, Ilić ZS, Šunić L, Andjelković S. The potential of different plant species for heavy metals accumulation and distribution Journal of Food, Agriculture \& Environment, Vol.10, No.1, 959-964, 2012.

[42] Atafar Z, Mesdaghinia A, Nouri J, Homaee M, Effect of fertilizer application on soil heavy, Environment Monitoring and Assesment, Vol. 160, No. 83, 2010.

[43] Talari ACS, Martinez MAG, Movasaghi Z, Rehman S, Rehman IU. Advances in Fourier transform infrared (FTIR) spectroscopy of biological tissues. Applied Spectroscopy Reviews Vol.52, No.5, 456-506, 2017. 